\title{
PHYSIOLOGICAL AND BIOCHEMICAL CHANGES DURING THE GROWTH OF CUSTARD APPLE (ANNONA SQUAMOSA L.) FRUIT CULTIVATED IN VIETNAM
}

\author{
Thuy T. LE*1, Trong V. LE ${ }^{2}$, Hang T.K. DOAN ${ }^{3}$, Khanh N. NGUYEN ${ }^{1}$ \\ ${ }^{1}$ Faculty of Biology, Hanoi National University of Education, Hanoi city, Vietnam \\ ${ }^{2}$ Faculty of Natural Sciences, Hongduc University, Thanhhoa City, Vietnam \\ ${ }^{3}$ Huu Lung High School, Lang Son Province, Vietnam \\ Received: May 2021; Accepted: December 2021
}

\begin{abstract}
This study evaluated some physiological and biochemical changes that accompanied the growth stages of custard apple cultivated in Lang Son, Vietnam. Regarding the pigment content of the peel, the research results showed that the content of chlorophyll a, b, and total reached the highest value at week 13, then decreased rapidly when the fruit entered the ripening stage. Meanwhile, carotenoid content in the peel increased gradually from week 3 until complete ripening at week 16 , from 0.014 to $0.063 \mathrm{mg} \cdot \mathrm{g}^{-1}$ fresh peel. Protein, lipid, and tannin content in the fruit flesh decreased gradually from week 3 to maturity. The vitamin $\mathrm{C}$ and reducing sugar content tended to reduce in week 3 to 7 , then increased again until the fruit ripened. While the starch content varied quite complicatedly, it decreased from week 3 to 7 , increased again from week 9 to 13 , then decreased sharply as the fruit entered the ripening stage (down from $10.011 \%$ at week 13 to $1.795 \%$ at week 16). Regarding enzyme activity, $\alpha$-amylase and peroxidase activity increased during the fruit development stages, corresponding to week 3 to 15 in this study. At week 16 , the peroxidase activity continued to increase, while the $\alpha$-amylase activity began to decrease. Unlike these two enzymes, catalase activity gradually increased from fruit formation to the 11th-week fruit stage, reaching $11.542 \mu \mathrm{M} \mathrm{H}_{2} \mathrm{O}_{2} \cdot \mathrm{g}^{-1} \cdot \mathrm{min}^{-1}$, and then decreased rapidly to $3.167 \mu \mathrm{M} \mathrm{H}_{2} \mathrm{O}_{2} \cdot \mathrm{g}^{-1} \cdot \mathrm{min}^{-1}$ in the 16th-week fruit stage.
\end{abstract}

Key words: biochemical indicator, custard apple, Annona squamosa, physiological indicator, ripening

\section{INTRODUCTION}

Annona squamosa L., commonly known as sugar or custard apple (Cheng et al. 2018), is a member of the Annonaceae family. The custard apple is native to the Americas. Currently, the plant is cultivated in tropical and subtropical regions around the world (Kabele Ngiefu et al. 1977; Yang et al. 2009). In Vietnam, the custard apple is widely grown in the north and the south of the country, concentrating in some provinces such as Lang Son, Quang Ninh, and Tay Ninh. The custard apple has a high economic value, contributing to poverty reduction and to recultivation and reforestation in some northern mountain provinces. Custard apple fruit has a high nutritional value and contains rich bioactive ingredients, including sugar, protein, vitamins, crude fiber, iron $(\mathrm{Fe})$, calcium $(\mathrm{Ca})$, phosphorus (P), and other mineral elements (Das et al. 2016; Pimpalpalle et al. 2018). In addition, all parts of A. squamosa tree (seeds, leaves, roots) are widely used as ethnic medicine against various ailments and diseases, especially cancer and parasitism, similar to other species within the genus (Gajalakshmi et al. 2011; Yadav et al. 2011; Liu et al. 2015; Ma et al. 2017; Souza et al. 2018). 
Maturity is the stage at which the fruit has reached its maximum growth and development. Most of the fruit reaches the highest edible quality in the fully ripe stage (Gundewadi et al. 2018). Fruits picked prematurely might lack flavor and may not ripen properly, while those picked too late might be fibrous or overripe (Kitinoja \& Kader 2002). These features are related to the physiological, biochemical, and physical changes that occur during the fruit ripening. In many fruits, the breakdown of starch to glucose, fructose, or sucrose is a characteristic ripening event (Souleyre et al. 2004; Gundewadi et al. 2018). A series of enzymes (including $\alpha$-amylase, $\beta$-amylase, or $\alpha$-glucosidase) are involved in the degradation of starch and the formation of its byproducts with the release of energy (Seymour et al. 2012). Variation in vitamin $C$ content is another example of biochemical changes during the fruit ripening. Observations show a gradual rise in ascorbic acid content with fruit growth, and the levels decline with the advancement of maturity and onset of fruit ripening and harvest handling. However, in certain crops, as pome, stone, and berry fruits, the ascorbic acid content was found to be low at the time of harvest (Wills et al. 2007). In addition, a change in fruit color, usually a loss of green color, is the most noticeable physical change in most fruits as they enter the ripening stage. The loss of green color during maturation and ripening is mainly due to the degradation of chlorophyll molecules, which is mediated by chlorophyllase enzyme, $\mathrm{pH}$ changes, oxidative stress, and synthesis of secondary metabolites, such as carotenoids, anthocyanins, and other pigments that mask the expression of chlorophyll pigment (Wills et al. 1998).

During ripening, variation in fruit color, shape, and size are common indicators to determine harvest time in many fruit species (Gundewadi et al. 2018). Custard apples are characterized by high respiration and ethylene production, so they are highly susceptible to spoilage, soften very rapidly during ripening. Using chemical treatments or different temperatures to prolong storage time has been shown in some studies (Cheng et al. 2018).
Besides preservation measures, the harvesting time also affects the quality and shelf life of the fruit (Pimpalpalle et al. 2018). In Vietnam, harvesting of the custard apples is often based on the experience of gardeners; popularly, the fruits are harvested when the crevices of the fruit are yellowwhite and large. Meanwhile, many studies have shown that the physiological and biochemical properties of most fruits change drastically when they enter the ripening stage. Therefore, the analysis of physiological and biochemical changes according to the fruit development stages helps determine the appropriate time to harvest custard apples. This result is important in ensuring the quality of the fruit during storage and use.

\section{MATERIALS AND METHODS}

\section{Research materials}

Custard apple fruits ('Na Dai' cultivar) were collected from the four-year-old orchard in Dong Tan commune, Huu Lung district, Lang Son province, Vietnam. Experiments in this research were analyzed at the Physiological Plant and Application Laboratory, Faculty of Biology, Hanoi National University of Education, Vietnam.

\section{Sample collection method}

Thirty healthy trees were selected from a total of 200 trees in a custard apple garden. Custard apple fruits were harvested in nine stages, beginning from week 3 to 16. Samples were collected according to the mixed sampling method. After collecting, samples were put into plastic bags with small ventilation holes, labeled, and transported to the laboratory for analysis.

The number of samples collected and used for the analysis of physiological and biochemical indicators in one stage was 30 .

\section{Analysis methods of physiological indicators Pigment content in the peel}

Determination of pigment content in the peel by the spectral method was made as per Ma et al. (2013). Took the green part of the fresh fruit peel with a sharp knife and accurately weighed $2 \mathrm{~g}$ into 
a porcelain mortar, crushed it and then added $80 \%$ acetone and centrifuged to collect the solution, and measured the solution on the spectrophotometer at the corresponding wavelengths. Chlorophyll content was calculated by the formula: $\mathrm{C}_{\mathrm{a}}\left(\mathrm{mg} \cdot \mathrm{L}^{-1}\right)=$ $9.784 \times \mathrm{E}_{662}-0.990 \times \mathrm{E}_{644} ; \mathrm{C}_{\mathrm{b}}\left(\mathrm{mg} \cdot \mathrm{L}^{-1}\right)=21.426$ $\times \mathrm{E}_{644}-4.650 \times \mathrm{E}_{662} ; \mathrm{C}_{(\mathrm{a}+\mathrm{b})}\left(\mathrm{mg} \cdot \mathrm{L}^{-1}\right)=5.134 \times \mathrm{E}_{662}$ $+20.436 \times \mathrm{E}_{644}$. Carotenoids content was calculated by the formula: $\mathrm{C}_{\mathrm{car}}\left(\mathrm{mg} \cdot \mathrm{L}^{-1}\right)=4.695 \times \mathrm{E}_{440.5}$ $-0.268 \times \mathrm{C}_{(\mathrm{a}+\mathrm{b})}$. Then the pigment content per $1 \mathrm{~g}$ of fresh fruit peel was calculated by the formula:

$$
\mathrm{A}=\frac{\mathrm{C} \times \mathrm{V}}{\mathrm{P} \times 1000} ;
$$

where $\mathrm{E}_{662}, \mathrm{E}_{644}$, and $\mathrm{E}_{440.5}$ are the results of measuring chlorophyll color at wavelengths of $662 \mathrm{~nm}$, $644 \mathrm{~nm}$, and $440.5 \mathrm{~nm} ; \mathrm{C}_{\mathrm{a}}, \mathrm{C}_{\mathrm{b}}$, and $\mathrm{C}_{(\mathrm{a}+\mathrm{b})}$ are respectively chlorophyll contents $\mathrm{a}, \mathrm{b}$, and total; $\mathrm{A}\left(\mathrm{mg} \cdot \mathrm{g}^{-1}\right)$ is the content of chlorophyll in $1 \mathrm{~g}$ of fresh fruit peel; $\mathrm{C}$ is the chlorophyll content of the pigment extract $\left(\mathrm{mg} \cdot \mathrm{L}^{-1}\right) ; \mathrm{V}$ is the volume of pigment extract $(10 \mathrm{~mL})$; and $\mathrm{P}$ is the sample mass $(\mathrm{g})$.

\section{Vitamin $C$ content}

Vitamin $\mathrm{C}$ content was determined by the iodine titration method (Arya et al. 2000), in which $5 \mathrm{~g}$ of fresh fruit flesh was triturated with $5 \mathrm{~mL}$ of $5 \%$ $\mathrm{HCl}$ in a ceramic bowl. It was ground and put in a volumetric flask where distilled water was added to the $50 \mathrm{~mL}$ mark and well stirred. Then, $20 \mathrm{~mL}$ of the solution was put in a $100 \mathrm{~mL}$ conical flask and titrated by $\mathrm{I}_{2}$ solution with starch as a color indicator until a blue color appeared, thereby determining the vitamin $\mathrm{C}$ content. The result was calculated based on the formula:

$$
\mathrm{X}=\frac{\mathrm{V} \times \mathrm{V} 1 \times 0.00088 \times 100}{\mathrm{~V} 2 \times \mathrm{g}} ;
$$

where $\mathrm{X}$ is the content of vitamin $\mathrm{C}$ in the materials $(\%)$; $\mathrm{V}$ is the volume of diluted sample solution $(\mathrm{mL})$; V1 is the volume of $0.01 \mathrm{~N} \mathrm{I}_{2}$ solution $(\mathrm{mL}) ; \mathrm{V} 2$ is the volume of analyzed solution $(\mathrm{mL}) ; \mathrm{g}$ is the weight of the sample $(\mathrm{g}) ; 0.00088$ is the weight $(\mathrm{g})$ of vitamin $\mathrm{C}$, which was equivalent to $1 \mathrm{~mL}$ of $0.01 \mathrm{~N} \mathrm{I}_{2}$; and 100 is the conversion factor to percent.

\section{Content of reducing sugar and starch}

Reducing sugar content and starch content was determined by the Bertrand method that was described by Mui (2001). Reducing sugar content was calculated using the following formula:

$$
\mathrm{X}=\frac{\mathrm{a} \times \mathrm{V} 1 \times 100}{\mathrm{~V} \times \mathrm{b} \times 1000}
$$

where $\mathrm{X}$ is the reducing sugar content (\%); a is the weight $(\mathrm{mg})$ of glucose obtained when examining the table for volume $\mathrm{KMnO}_{4} 1 / 30 \mathrm{~N}$ (mL) used for titration of the laboratory sample minus the volume $\mathrm{KMnO}_{4} 1 / 30 \mathrm{~N}(\mathrm{~mL})$ titration in the control sample; $\mathrm{V}$ is the volume of the diluted sample solution $(\mathrm{mL})$; V1 is the volume of the analyzed sample solution $(\mathrm{mL})$; $b$ is the weight of the test sample $(\mathrm{g})$; 100 is the conversion factor to percent; and 1000 is the coefficient converts grams to milligrams.

The starch content was calculated by the formula:

$$
\mathrm{Y}=\frac{\mathrm{a} \times \mathrm{V} 1 \times 100 \times 0.9}{\mathrm{~V} 2 \times \mathrm{b}}
$$

where $\mathrm{Y}$ is the content of starch (\%); a is the amount of reducing sugar; V1 is the volume of analyzed sample solution $(\mathrm{mL})$; $\mathrm{V} 2$ is the volume of diluted sample solution $(\mathrm{mL})$; b is the weight of the analyzed sample $(\mathrm{g}) ; 100$ is the conversion factor to percent; and 0.9 is the coefficient of converting glucose into starch.

\section{Tannin content}

Determination of tannin content was by the Leventhal method (Chau et al. 1998), in which $2 \mathrm{~g}$ of crushed dried fruit pulp was added to a heat-resistant conical flask, and tannin was extracted by adding $100 \mathrm{ml}$ of distilled water to the flask. It was boiled for 40 minutes in a water bath, then filtered to collect the solution. Extraction was continued until the filtrate was no longer reactive with tannins. The extract was then cooled and quantified through titration with $\mathrm{KMnO}_{4}$. The tannin content was calculated by the formula:

$$
\mathrm{X}=\frac{(\mathrm{a}-\mathrm{b}) \times \mathrm{V} \times \mathrm{k} \times 100}{\mathrm{~V} 1} ;
$$


where $\mathrm{X}$ is the tannin content (\%) in dried weight; $\mathrm{a}$ is the volume of $\mathrm{KMnO}_{4} 0.1 \mathrm{~N}$ used for titration in the flask (mL); b is the volume of $\mathrm{KMnO}_{4} 0.1 \mathrm{~N}$ used for titration in the control vessel $(\mathrm{mL})$; $\mathrm{V}$ is the total volume of extract $(\mathrm{mL}) ; \mathrm{V} 1$ is the volume of the analyzed extract $(\mathrm{mL})$; $b$ is the weight of the analyzed sample $(\mathrm{g})$; and $\mathrm{k}$ is the tannin coefficient and is 0.00582 (every $1 \mathrm{~mL} \mathrm{KMnO}_{4} 0.1 \mathrm{~N}$ is equivalent to $0.00582 \mathrm{~g}$ tannin).

\section{Total organic acid content}

Determination of total organic acid content by titration method is described by Ermakov et al. (1972). The total organic acid content in fresh fruit flesh was calculated by the formula:

$$
\mathrm{X}=\frac{\mathrm{a} \times \mathrm{V} 1 \times 100}{\mathrm{~V} 2 \times \mathrm{p}}
$$

where $\mathrm{X}$ is the amount of total organic acid present in the extract $\left(\mathrm{mg} \cdot 100 \mathrm{~g}^{-1}\right.$ fresh fruit); $\mathrm{P}$ is the amount of analytical sample (g); V1 is the total volume of extract $(\mathrm{mL})$; V2 is the volume to be titrated $(\mathrm{mL})$; and a is the amount of $0.1 \mathrm{~N} \mathrm{NaOH}$ titration $(\mathrm{mL})$.

\section{Protein content}

Protein content was estimated by the microKjeldahl method (Mui 2001)

$$
\mathrm{A}=\frac{\mathrm{V} \times \mathrm{Va} \times 0.142 \times 5.595 \times 100}{\mathrm{Vc} \times \mathrm{g}} ;
$$

where $\mathrm{A}$ is the protein content (\%); $\mathrm{Va}$ is the volume of $\mathrm{H}_{2} \mathrm{SO}_{4} 0.01 \mathrm{~N}$ used to titrate $\mathrm{BO}_{2} ; \mathrm{V}$ is the total volume of enzyme extract $(\mathrm{mL})$; $\mathrm{Vc}$ is the volume of $\mathrm{NH}_{3}$ in analytical extract $(\mathrm{mL})$; $\mathrm{g}$ is the weight of the crushed sample $(\mathrm{g}) ; 0.142 \mathrm{mg} \mathrm{N}$ is equivalent to $1 \mathrm{ml} \mathrm{H}_{2} \mathrm{SO}_{4} 0.01 \mathrm{~N} ; 5.595$ is the conversion factor to indicate the result of protein; and 100 is the conversion factor to percent.

\section{Lipid content}

Lipid content was determined by the Soxhlet method (Mui 2001). The fruit flesh was crushed, dried to constant weight, then the sample was put in a paper bag and placed in the extraction cylinder. The lipid content was calculated by the formula:

$$
X=\frac{G m-G c}{G} \times 100 ;
$$

where $\mathrm{X}$ is the lipid content (\%); $\mathrm{Gm}$ is the mass of the dry sample pack before extraction ( $\mathrm{g}$ ); Gc is the mass of lipid-extracted dry sample pack $(\mathrm{g})$; and $G$ is the mass of the initial sample taken for analysis $(\mathrm{g})$.

\section{$\alpha$-amylase activity}

The enzyme activity was determined using a spectrophotometer at $656 \mathrm{~nm}$ wavelength (Mui 2001). $\alpha$-amylase enzyme activity was calculated by the formula:

$$
\mathrm{A}=\frac{6.889 \times \mathrm{c}-0.089388}{\mathrm{~W}}
$$

and $\mathrm{c}$ was calculated by the formula:

$$
\mathrm{c}=\frac{\mathrm{OD} 1 \times \mathrm{OD} 2}{\mathrm{OD} 1} \times 0.1
$$

where A is $\alpha$-amylase enzyme activity (UI $\cdot \mathrm{g}^{-1} \cdot \mathrm{h}^{-1}$ ); $\mathrm{C}$ is the amount of starch hydrolyzed (g); OD1 is the optical density at the control vessel; OD2 is the optical density at the experimental flask; 0.1 is the amount of starch analyzed; $\mathrm{W}$ is the amount of analytical enzyme composition (g); and 6.889 and 0.089388 are the coefficients of the equation for the activity obtained by the mathematical processing method.

\section{Catalase activity}

The activity was estimated by the A.N. Bac and A.I. Oparin method (Mui 2001). Catalase enzyme activity was calculated by the formula:

$$
\mathrm{X}=\frac{(\mathrm{V} 1-\mathrm{V} 2) \times 1.7 \times \mathrm{Vx}}{\mathrm{Vc} \times 30 \times 0.034 \times \mathrm{a}} \times 0.1
$$

where $\mathrm{X}\left(\mu \mathrm{M} \mathrm{H}_{2} \mathrm{O}_{2} \cdot \mathrm{g}^{-1} \cdot \mathrm{min}^{-1}\right)$ is the catalase activity calculated by the number of micromol $\mathrm{H}_{2} \mathrm{O}_{2}$ resolved in 1 minute under the action of catalase enzyme in $1 \mathrm{~g}$ sample at $30^{\circ} \mathrm{C}$; $\mathrm{V} 1$ is the volume of $\mathrm{KMnO}_{4} 0.1 \mathrm{~N}$ used to titrate $\mathrm{H}_{2} \mathrm{O}_{2}$ in the control vessel $(\mathrm{mL})$; V2 is the volume of $\mathrm{KMnO}_{4} 0.1 \mathrm{~N}$ used to titrate $\mathrm{H}_{2} \mathrm{O}_{2}$ in the experimental flask (mL); $\mathrm{Vx}$ is the total volume of enzyme extract $(\mathrm{mL}) ; \mathrm{Vc}$ is the volume of analytical extract $(\mathrm{mL})$; $a$ is the weight of the crushed sample $(\mathrm{g}) ; 1.7$ is the conversion coefficient from the titrant $\mathrm{KMnO}_{4} 0.1 \mathrm{~N}$ 
to $\mathrm{mg} \mathrm{H}_{2} \mathrm{O}_{2}$ resolved; 30 is the duration of enzyme action ( $\mathrm{min}$ ); and 0.034 is the conversion factor of milligrams to micromoles.

\section{Peroxidase activity}

Peroxidase activity was determined using the A.N. Boiarkin method on a spectrophotometer (Mui 2001): Peroxidase enzyme activity was calculated by the formula:

$$
A=\frac{E \times a \times b}{p \times d \times t}
$$

where $\mathrm{A}\left(\mathrm{UI} \cdot \mathrm{g}^{-1} \cdot \mathrm{s}^{-1}\right)$ is the peroxidase activity in $1 \mathrm{~g}$ of sample; $\mathrm{E}$ is the selected optical density; $a$ is the total volume of extract $(\mathrm{mL})$; $b$ is the degree of extract dilution; $p$ is the weight of the plant sample $(\mathrm{g})$; $\mathrm{d}$ is the cup thickness $(\mathrm{cm})$; and $\mathrm{t}$ is the time (s).

\section{Statistical analysis}

All experiments were conducted three times independently. The results are expressed as mean values and standard deviation (SD). The results were subjected to an analysis of variance. Data were compared according to Tukey's test using IRRISTAT software (version 5.0) for Windows computers (IRRI 2005).

\section{RESULTS AND DISCUSSION}

\section{Change in the pigment content of the custard apple peel}

During maturation, unlike other fruits, such as mango, persimmon, and tomato, although there is no noticeable discoloration in the custard apple, slight changes in color on the peel are also a sign of ripening.

Results in Table 1 show that the content of chlorophyll a, b, and total in fruit peel increase from week 3 to 13. After that, chlorophyll content decreased gradually from week 14 to 16 . The chlorophyll content reached the highest value at week 13 , specifically, the content of chlorophyll a was $0.046 \mathrm{mg} \cdot \mathrm{g}^{-1}$ fresh peel, chlorophyll b was $0.095 \mathrm{mg} \cdot \mathrm{g}^{-1}$, and total chlorophyll was $0.141 \mathrm{mg} \cdot \mathrm{g}^{-1}$ fresh peel.

The carotenoid content of the peel increased from fruit formation to maturity. Specifically, in the fruit development stage from week 3 to 13, the content of carotenoid increased slowly from 0.014 to $0.027 \mathrm{mg} \cdot \mathrm{g}^{-1}$ fresh peel, doubling after week 10 of development. Meanwhile, with only 2 weeks of growth, from week 13 to 15 , carotenoid content in the peel increased nearly 2.5 times, reaching a value of $0.065 \mathrm{mg} \cdot \mathrm{g}^{-1}$. When the fruit was ripe, at week 16 , this content tended to decrease slightly to a value of $0.063 \mathrm{mg} \cdot \mathrm{g}^{-1}$.

Table 1. Content of chlorophylls in custard apple peel at different stages of fruit development

\begin{tabular}{ccccc}
\hline $\begin{array}{c}\text { Time of fruit } \\
\text { growth }\end{array}$ & $\begin{array}{c}\text { Chlorophyll a } \\
\left(\mathrm{mg} \cdot \mathrm{g}^{-1} \text { fresh peel }\right)\end{array}$ & $\begin{array}{c}\text { Chlorophyll b } \\
\left(\mathrm{mg} \cdot \mathrm{g}^{-1} \text { fresh peel }\right)\end{array}$ & $\begin{array}{c}\text { Chlorophyll }(\mathrm{a}+\mathrm{b}) \\
\left(\mathrm{mg} \cdot \mathrm{g}^{-1} \text { fresh peel }\right)\end{array}$ & $\begin{array}{c}\text { Carotenoid content } \\
\left(\mathrm{mg} \cdot \mathrm{g}^{-1} \text { fresh peel }\right)\end{array}$ \\
\hline week 3 & $0.011^{\mathrm{f}} \pm 0.001$ & $0.025^{\mathrm{g}} \pm 0.002$ & $0.036^{\mathrm{h}} \pm 0.001$ & $0.014^{\mathrm{e}} \pm 0.002$ \\
\hline week 5 & $0.020^{\mathrm{e}} \pm 0.002$ & $0.037^{\mathrm{f}} \pm 0.001$ & $0.057^{\mathrm{g}} \pm 0.001$ & $0.016^{\mathrm{de}} \pm 0.002$ \\
\hline week 7 & $0.027^{\mathrm{d}} \pm 0.002$ & $0.064^{\mathrm{d}} \pm 0.002$ & $0.091^{\mathrm{e}} \pm 0.002$ & $0.016^{\mathrm{de}} \pm 0.001$ \\
\hline week 9 & $0.036^{\mathrm{c}} \pm 0.003$ & $0.076^{\mathrm{c}} \pm 0.001$ & $0.112^{\mathrm{c}} \pm 0.005$ & $0.017^{\mathrm{e}} \pm 0.001$ \\
\hline week 11 & $0.041^{\mathrm{b}} \pm 0.001$ & $0.086^{\mathrm{b}} \pm 0.002$ & $0.127^{\mathrm{b}} \pm 0.003$ & $0.019^{\mathrm{d}} \pm 0.002$ \\
\hline week 13 & $0.046^{\mathrm{a}} \pm 0.001$ & $0.095^{\mathrm{a}} \pm 0.002$ & $0.141^{\mathrm{a}} \pm 0.001$ & $0.027^{\mathrm{c}} \pm 0.003$ \\
\hline week 14 & $0.040^{\mathrm{b}} \pm 0.001$ & $0.061^{\mathrm{d}} \pm 0.003$ & $0.101^{\mathrm{d}} \pm 0.003$ & $0.051^{\mathrm{b}} \pm 0.004$ \\
\hline week 15 & $0.025^{\mathrm{d}} \pm 0.001$ & $0.051^{\mathrm{e}} \pm 0.002$ & $0.077^{\mathrm{f}} \pm 0.002$ & $0.065^{\mathrm{a}} \pm 0.002$ \\
\hline week 16 & $0.021^{\mathrm{e}} \pm 0.002$ & $0.020^{\mathrm{h}} \pm 0.002$ & $0.041^{\mathrm{g}} \pm 0.002$ & $0.063^{\mathrm{a}} \pm 0.004$ \\
\hline
\end{tabular}

Numbers represent mean values of three independent replicates \pm SD. In the same data column, values with similar letters represent nonsignificant differences, values with different letters represent significant differences $(\mathrm{p}<0.05)$ by Tukey's test 
This change in pigment content is consistent with the change of color observed on the pods during the fruit growth. The newly formed fruit is pale green, then turns dark green (Gundewadi et al. 2018). When the fruit is nearly ripe, the green color gradually fades, turning white to yellow ( $\mathrm{Pal} \&$ Sampath Kumar 1995). This result is consistent with some studies that chlorophyll decomposition is related to the maturity of fruit (Du et al. 2014).

Changes in the content of reducing sugars, starch, and tannins

For most fruits, the reducing sugar content increases as the fruit enters the ripening stage (Paull et al. 1983). Some previous reports on mango or persimmon showed that the reducing sugars content tends to increase from the early stage to the maturity stage of the fruit (Trong et al. 2020a, b). In the present study on the custard apple, we did not observe a similar pattern of change. The data in Table 2 show that the content of reducing sugars in custard apple decreased gradually from week 3 to 7 by about $50 \%$. The content of these sugars remained constant in the fruits until week 9 , then increased sharply from week 14 to a peak at week 16, when it was 8.3 times higher than at week 3 (Table 2).
This increase is higher than that announced in tomatoes (2 times) and mangoes (3.5 times) (Trong et al. 2019, 2020b).

Similar to the results of reducing sugar content analysis, the starch content in the custard apple decreased gradually from week 3 to 7 , then increased and reached the maximum value at week 13 , before decreasing gradually due to ripening fruit. The starch content of fruit at week 16 was $1.795 \%$, only equal to $17.9 \%$ of the starch content at the week 13. The starch content decreased rapidly when the fruit was ripe following the increase in reducing sugar content of the custard apple as analyzed above.

The tannins in custard apple fruit had a relatively high content, reaching $11.410 \%$ at week 3 . The high content of tannin in the early period made the fruit acrid and hard. The tannin content gradually decreased with the fruit development and dropped sharply until week 13. This decline is due to the breakdown of the hydrolytic tannins into pyrogallol and $\mathrm{CO}_{2}$, which causes the fruit to ripen (Del Bubba et al. 2009). In the stage of fruit maturity, tannin content had dropped to only $0.582 \%$ at week 16 ; this result made the custard apple soft, not sour.

Table 2. Content of reducing sugars, starch, and tannins in the custard apple at different stages of fruit development

\begin{tabular}{cccc}
\hline $\begin{array}{c}\text { Time of fruit } \\
\text { growth }\end{array}$ & $\begin{array}{c}\text { Reducing sugar content } \\
\text { (\% of fresh fruit weight })\end{array}$ & $\begin{array}{c}\text { Starch content } \\
\text { (\% of fresh fruit weight })\end{array}$ & $\begin{array}{c}\text { Tannin content } \\
\text { (\% of dried fruit weight })\end{array}$ \\
\hline week 3 & $1.633^{\mathrm{e}} \pm 0.087$ & $2.444^{\mathrm{f}} \pm 0.042$ & $11.400^{\mathrm{a}} \pm 0.641$ \\
\hline week 5 & $1.181^{\mathrm{f}} \pm 0.082$ & $2.111^{\mathrm{f}} \pm 0.020$ & $10.961^{\mathrm{a}} \pm 0.928$ \\
\hline week 7 & $0.830^{\mathrm{g}} \pm 0.042$ & $1.143^{\mathrm{h}} \pm 0.029$ & $8.730^{\mathrm{b}} \pm 0.420$ \\
\hline week 9 & $1.175^{\mathrm{f}} \pm 0.050$ & $3.249^{\mathrm{e}} \pm 0.030$ & $5.820^{\mathrm{c}} \pm 0.210$ \\
\hline week 11 & $1.783^{\mathrm{e}} \pm 0.104$ & $6.003^{\mathrm{c}} \pm 0.104$ & $4.244^{\mathrm{d}} \pm 0.121$ \\
\hline week 13 & $2.072^{\mathrm{d}} \pm 0.023$ & $10.011^{\mathrm{a}} \pm 0.511$ & $2.037^{\mathrm{e}} \pm 0.151$ \\
\hline week 14 & $5.136^{\mathrm{c}} \pm 0.047$ & $8.692^{\mathrm{b}} \pm 0.403$ & $1.407^{\mathrm{f}} \pm 0.253$ \\
\hline week 15 & $10.972^{\mathrm{b}} \pm 0.308$ & $4.819^{\mathrm{d}} \pm 0.687$ & $0.728^{\mathrm{g}} \pm 0.042$ \\
\hline week 16 & $13.577^{\mathrm{a}} \pm 0.331$ & $1.795^{\mathrm{g}} \pm 0.062$ & $0.582^{\mathrm{g}} \pm 0.035$ \\
\hline
\end{tabular}

Note: see Table 1 
Changes in the content of proteins, lipids, total organic acids and vitamin $\mathbf{C}$

The results in Table 3 show that the contents of proteins, lipids, and total organic acids tend to decrease gradually depending on the development stage of custard apple. The vitamin $\mathrm{C}$ content fluctuates more complicatedly. It decreased from week 3 to 7 , and then increased again from week 9 to 15 , while at week 16 it began to decrease. The protein content of the fruit was highest at week 3 , reaching $11.175 \%$; this content was almost halved to $6.15 \%$ when the fruit ripened at week 16. Likewise, the lipid content also decreased from $11.45 \%$ (week 3) to $4.588 \%$ (week 16). As the fruit enters the ripening stage, vigorous action of proteases and lipases can lead to rapid hydrolysis of proteins and lipids in the flesh. The proteins content of the fruit decreased during growth and development because the proteins in fruit mainly act as enzymes and not reserves (Wills et al. 1998).

In persimmons and mangoes, the total organic acids contents usually increased gradually and reached the maximum value when the fruit entered the ripening stage (Trong et al. 2020a, b). Unlike these fruits, the total organic acids content was highest during the early stage of custard apple fruit development. Total organic acids content obtained at this stage (week 3) was $97.917 \mathrm{mg} \cdot 100 \mathrm{~g}^{-1}$ fresh fruit. During subsequent fruit development, the total organic acids content decreased gradually, and decreased most strongly at the ripening stage. In comparison with week 3 , at week 16 , the organic acid content decreased more than four times, and was $22.860 \mathrm{mg} \cdot 100 \mathrm{~g}^{-1}$ fresh fruit. This content sharp drop may be related to the participation of organic acids in energy respiration. On the other hand, energy continues to be needed for the biosynthesis of fruit-specific ripening substances, such as enzymes for hydrolysis, esters to create an aroma, and synthesis of sugars to create sweetness of fruits, resulting in a decrease in total acids content (Prasanna et al. 2007).

Vitamin $\mathrm{C}$ is an important nutritional indicator to evaluate the quality of many fruits. The amount of vitamin $C$ in the custard apple varied quite complicatedly according to the development of the fruit. The analytical results showed that the vitamin $\mathrm{C}$ content in the flesh was relatively high when the fruit was newly formed, reaching $32.467 \mathrm{mg} \cdot 100 \mathrm{~g}^{-1}$ fresh fruit, then gradually decreasing to $18.667 \mathrm{mg} \cdot 100 \mathrm{~g}^{-1}$ fresh fruit at week 7. From week 7 to week 15, vitamin $\mathrm{C}$ content increased again. The highest vitamin $\mathrm{C}$ content was measured at week 15 , reaching $36.2 \mathrm{mg} \cdot 100 \mathrm{~g}^{-1}$ fresh fruit. After that, vitamin $\mathrm{C}$ content decreased slightly to $35.5 \mathrm{mg} \cdot 100 \mathrm{~g}^{-1}$ fresh fruit when the fruit was fully ripe at the week 16. Vitamin $\mathrm{C}$ decreased due to its participation in the biosynthesis of ethylene, oxalate, and tartrate in the fruit (Singh et al. 2011).

Table 3. Content of proteins, lipids, total organic acids and vitamin $\mathrm{C}$ in the custard apple at different stages of fruit development

\begin{tabular}{ccccc}
\hline $\begin{array}{c}\text { Time } \\
\text { of fruit } \\
\text { growth }\end{array}$ & $\begin{array}{c}\text { Proteins content } \\
\text { (\% of dried fruit weight })\end{array}$ & $\begin{array}{c}\text { Lipids content } \\
\text { of dried fruit weight })\end{array}$ & $\begin{array}{c}\text { Total organic acids content } \\
\left(\mathrm{mg} \cdot 100 \mathrm{~g}^{-1} \text { fresh fruit }\right)\end{array}$ & $\begin{array}{c}\text { Vitamin C content } \\
\left(\mathrm{mg} \cdot 100 \mathrm{~g}^{-1} \text { fresh fruit }\right)\end{array}$ \\
\hline week 3 & $11.175^{\mathrm{a}} \pm 1.281$ & $11.450^{\mathrm{a}} \pm 1.304$ & $97.917^{\mathrm{a}} \pm 1.102$ & $32.467^{\mathrm{b}} \pm 2.897$ \\
\hline week 5 & $9.812^{\mathrm{b}} \pm 1.002$ & $9.583^{\mathrm{b}} \pm 1.287$ & $78.333^{\mathrm{b}} \pm 2.205$ & $22.125^{\mathrm{de}} \pm 1.654$ \\
\hline week 7 & $8.718^{\mathrm{c}} \pm 0.987$ & $8.718^{\mathrm{bc}} \pm 1.334$ & $59.167^{\mathrm{c}} \pm 3.835$ & $18.667^{\mathrm{ef}} \pm 1.376$ \\
\hline week 9 & $8.618^{\mathrm{c}} \pm 0.930$ & $8.127^{\mathrm{c}} \pm 1.311$ & $53.750^{\mathrm{cd}} \pm 2.722$ & $20.680^{\mathrm{e}} \pm 2.684$ \\
\hline week 11 & $8.268^{\mathrm{dc}} \pm 0.810$ & $7.789^{\mathrm{dc}} \pm 0.959$ & $49.583^{\mathrm{d}} \pm 4.463$ & $24.267^{\mathrm{d}} \pm 2.230$ \\
\hline week 13 & $7.925^{\mathrm{d}} \pm 0.821$ & $7.512^{\mathrm{d}} \pm 0.870$ & $43.750^{\mathrm{de}} \pm 3.715$ & $26.133^{\mathrm{cd}} \pm 2.467$ \\
\hline week 14 & $7.868^{\mathrm{d}} \pm 0.645$ & $6.896^{\mathrm{de}} \pm 0.852$ & $36.250^{\mathrm{e}} \pm 4.722$ & $27.267^{\mathrm{bc}} \pm 3.450$ \\
\hline week 15 & $7.181^{\mathrm{de}} \pm 0.694$ & $6.320^{\mathrm{e}} \pm 0.572$ & $29.667^{\mathrm{f}} \pm 3.833$ & $36.200^{\mathrm{a}} \pm 3.336$ \\
\hline week 16 & $6.150^{\mathrm{e}} \pm 0.536$ & $4.588^{\mathrm{f}} \pm 0.169$ & $22.860^{\mathrm{g}} \pm 2.735$ & $35.500^{\mathrm{ab}} \pm 3.489$ \\
\hline
\end{tabular}

Note: see Table 1 
Changes in the activity of $\alpha$-amylase, catalase, and peroxidase

Table 4 shows that the $\alpha$-amylase activity of custard apple is lowest at week 3 and highest at week 15 . Amylase enzyme activity increased slowly from week 3 to week 11, while this activity increased sharply between week 11 and 13, more than four times after week 2 , from 2.460 to $9.958 \mathrm{UI} \cdot \mathrm{g}^{-1} \cdot \mathrm{h}^{-1}$. Then, amylase activity continued to increase and peaked at week $15\left(12.208 \mathrm{UI} \cdot \mathrm{g}^{-1} \cdot \mathrm{h}^{-1}\right)$. After that, it tended to decrease slightly to $11.167 \mathrm{UI} \cdot \mathrm{g}^{-1} \cdot \mathrm{h}^{-1}$ at week 16 . The $\alpha$-amylase activity change during the fruit development is consistent with the change in the sugar and starch content of the fruit when the fruit was ripe (Jain et al. 2001). This result was similar to the result of $\alpha$-amylase activity analysis in some other fruits such as persimmons, tomatoes, and mangoes (Trong et al. 2019, 2020a, b).

In the early stages of fruit development, the activity of catalase was relatively high $(2.083 \mu \mathrm{M}$ $\mathrm{H}_{2} \mathrm{O}_{2} \cdot \mathrm{g}^{-1} \cdot \mathrm{min}^{-1}$ at week 3). This value increased significantly from the fruiting stage of week 3 to 11 and then gradually decreased. The highest catalase activity $-11.542 \mu \mathrm{M} \mathrm{H} \mathrm{H}_{2} \mathrm{O}_{2} \cdot \mathrm{g}^{-1} \cdot \mathrm{min}^{-1}$ was measured at week 11 . The variability of the activity of antioxidant enzymes during ripening depends on the fruit species. For example, an increase in catalase activity was found in tomatoes during ripening (Andrews et al. 2004), while a decrease in oranges
(Huang et al. 2007) and mangoes (Singh \& Dwivedi 2008). In guavas, the activities of antioxidant enzymes, including catalase, reached maxima at the stage of color change and decreased at later stages (Mondal et al. 2009). This variability in the behavior of antioxidant enzymes can be attributed to differences in the activity of isoenzymes (Resende et al. 2012).

Both catalases and peroxidases play a role in the destruction of $\mathrm{H}_{2} \mathrm{O}_{2}$ but they use different mechanisms that are competitive. When the concentration of $\mathrm{H}_{2} \mathrm{O}_{2}$ in the cell is high, the catalase is highly active. Conversely, when the $\mathrm{H}_{2} \mathrm{O}_{2}$ concentration is low and the reducing agent is present, the peroxidase is highly active (Mui 2001). Accordingly, unlike the change in the activity of the catalase, the activity of the peroxidase increased continuously during the fruit growth and development. From week 3 to week 11 , peroxidase activity increased slowly (from $0.097 \mathrm{UI} \cdot \mathrm{g}^{-1} \cdot \mathrm{s}^{-1}$ to $0.226 \mathrm{UI} \cdot \mathrm{g}^{-1} \cdot \mathrm{s}^{-1}$ ); this was a period when the high concentration of $\mathrm{H}_{2} \mathrm{O}_{2}$ in the cell was lowered mainly by catalase activity. From week 11 to soft ripening (week 16), the peroxidase activity, reaching $0.858 \mathrm{UI} \cdot \mathrm{g}^{-1} \cdot \mathrm{s}^{-1}$, was about four times higher compared to the data obtained at week 11. This result may be related to a rapid tannin degradation, synthesis of several aromatic ring compounds and ethylene during the fruit ripening, which are catalyzed by peroxidase (Pandey et al. 2017).

Table 4 . The activity of enzymes $\alpha$-amylase, catalase, and peroxidase in the custard apple at different maturation stages

\begin{tabular}{cccc}
\hline $\begin{array}{c}\text { Time } \\
\text { of fruit growth }\end{array}$ & $\begin{array}{c}\alpha \text {-amylase activity } \\
\left(\mathrm{UI} \cdot \mathrm{g}^{-1} \cdot \mathrm{h}^{-1}\right)\end{array}$ & $\begin{array}{c}\text { Catalase activity } \\
\left(\mu \mathrm{M} \mathrm{H} \mathrm{O}_{2} \cdot \mathrm{g}^{-1} \cdot \mathrm{min}^{-1}\right)\end{array}$ & $\begin{array}{c}\text { Peroxidase activity } \\
\left(\mathrm{UI} \cdot \mathrm{g}^{-1} \cdot \mathrm{s}^{-1}\right)\end{array}$ \\
\hline week 3 & $0.032^{\mathrm{g}} \pm 0.001$ & $2.083^{\mathrm{g}} \pm 0.440$ & $0.097^{\mathrm{g}} \pm 0.003$ \\
\hline week 5 & $0.055^{\mathrm{f}} \pm 0.004$ & $2.917^{\mathrm{fg}} \pm 0.830$ & $0.125^{\mathrm{f}} \pm 0.012$ \\
\hline week 7 & $0.076^{\mathrm{ef}} \pm 0.006$ & $6.792^{\mathrm{ce}} \pm 0.923$ & $0.167^{\mathrm{e}} \pm 0.017$ \\
\hline week 9 & $0.093^{\mathrm{e}} \pm 0.007$ & $10.833^{\mathrm{ab}} \pm 1.167$ & $0.193^{\mathrm{e}} \pm 0.009$ \\
\hline week 11 & $2.460^{\mathrm{d}} \pm 0.017$ & $11.542^{\mathrm{a}} \pm 1.261$ & $0.226^{\mathrm{d}} \pm 0.006$ \\
\hline week 13 & $9.958^{\mathrm{c}} \pm 0.232$ & $9.958^{\mathrm{bc}} \pm 1.032$ & $0.403^{\mathrm{cd}} \pm 0.003$ \\
\hline week 14 & $11.917^{\mathrm{ab}} \pm 0.83$ & $8.917^{\mathrm{c}} \pm 0.830$ & $0.505^{\mathrm{c}} \pm 0.022$ \\
\hline week 15 & $12.208^{\mathrm{a}} \pm 0.950$ & $5.208^{\mathrm{e}} \pm 0.650$ & $0.796^{\mathrm{b}} \pm 0.013$ \\
\hline week 16 & $11.167^{\mathrm{b}} \pm 0.88$ & $3.167^{\mathrm{f}} \pm 0.88$ & $0.858^{\mathrm{a}} \pm 0.026$ \\
\hline
\end{tabular}

Note: see Table 1 


\section{CONCLUSIONS}

This study on the physiological and biochemical changes during developing of custard apple fruits has shown that the chlorophylls content in the peel increased gradually until week 13 , then it decreased gradually and reached the lowest value in the fully ripe custard apple (week 16).

The carotenoids content increased steadily until the fruit ripened, especially rapidly from week 13 to 15. Carbohydrate metabolism was reflected in a decrease in the content of reducing sugars and starch from fruit formation to week 7 . Thereafter, reducing sugars content increased sharply and was stored in ripe fruit, while the starch content peaked at week 13, and then dropped sharply, corresponding to a sharp increase in amylase activity.

The total acid content of custard apple was the highest value at week 3, reaching $97.917 \mathrm{mg} \cdot 100 \mathrm{~g}^{-1}$, then it decreased continuously and reached the lowest value $\left(22.860 \mathrm{mg} \cdot 100 \mathrm{~g}^{-1}\right)$ in the fruit ripening stage (week 16). The vitamin C content decreased from the stage of young fruit to week 7 , then gradually increased and peaked at week 15 .

The contents of proteins, lipids, and tannins of the dried fruit flesh decreased gradually from the young until the ripe fruit. Catalase activity in fruits increased to reach the maximum value at week 11 (11.542 $\left.\mu \mathrm{M} \mathrm{H}_{2} \mathrm{O}_{2} \cdot \mathrm{g}^{-1} \cdot \mathrm{min}^{-1}\right)$, then decreased gradually with the ripening. Peroxidase activity increased continuously throughout fruit development and was the lowest at week $3\left(0.097 \mathrm{UI} \cdot \mathrm{g}^{-1} \cdot \mathrm{s}^{-1}\right)$ and the highest at week $16\left(0.858 \mathrm{UI} \cdot \mathrm{g}^{-1} \cdot \mathrm{s}^{-1}\right)$.

Based on these results, custard apples should be harvested at week 15 before they are fully ripe to facilitate storage and ensure high postharvest quality.

\section{REFERENCES}

Andrews P.K., Fahy D.A., Foyer C.H. 2004. Relationships between fruit exocarp antioxidants in the tomato ( $L y$ copersicum esculentum) high pigment-1 mutant during development. Physiologia Plantarum 120(4): 519-528. DOI: 10.1111/j.0031-9317.2004.0279.x.

Arya S.P., Mahajan M., Jain P. 2000. Non-spectrophotometric methods for the determination of Vitamin C. Analytica Chimica Acta 417(1): 1-14. DOI: 10.1016/s0003-2670(00)00909-0.

Chau P.T.T., Hien N.T., Tuong P.G. 1998. Biochemistry Practice, 2nd ed. Educational Publishing House, Vietnam, 130 p. [in Vietnamese]
Cheng Z., Zhou W., Gong X., Wei X., Li J., Peng Z. 2018. Physicochemical changes of custard apple at different storage temperatures. IOP Conference Series Materials Science and Engineering 392(5); 052013; 5 p. DOI: 10.1088/1757-899x/392/5/052013.

Das S., Bhattacharya A., Ghosh B., Maji H.S. 2016. Analytical and phytochemical exploration of the seeds of Annona squamosa. Journal of Analytical and Pharmaceutical Research 3(4); 5 p. DOI: 10.15406/japlr.2016.03.00065

Del Bubba M., Giordani E., Pippucci L., Cincinelli A., Checchini L., Galvan P. 2009. Changes in tannins, ascorbic acid and sugar content in astringent persimmons during on-tree growth and ripening and in response to different postharvest treatments. Journal of Food Composition and Analysis 22(7-8): 668-677.DOI: 10.1016/j.jfca.2009.02.015

Du L., Yang X., Song J., Ma Z., Zhang Z., Pang X. 2014. Characterization of the stage dependency of high temperature on green ripening reveals a distinct chlorophyll degradation regulation in banana fruit. Scientia Horticulturae 180: 139-146. DOI: 10.1016/j.scienta.2014.10.026.

Ermakov A.I., Arasimovich V.V., Smirnova-Ikonnikova M.I., Yarosh N.P., Lukovnikova G.A. 1972. Methods for the Biochemical Analysis of Plants, 2nd ed. Kolos, Leningrad, 456 p. [in Russian]

Gajalakshmi S., Divya R., Divya Deepika V., Mythili S., Sathiavelu A. 2011. Pharmacological activities of Annona squamosa: A review. International Journal of Pharmaceutical Sciences Review and Research 10(2): 24-29.

Gundewadi G., Reddy V.R., Bhimappa B.B. 2018. Physiological and biochemical basis of fruit development and ripening - a review. Journal of Hill Agriculture 9(1): 7-21. DOI: 10.5958/2230-7338.2018.00003.4.

Huang R., Xia R., Hu L., Lu Y., Wang M. 2007. Antioxidant activity and oxygen-scavenging system in orange pulp during fruit ripening and maturation. Scientia Horticulturae 113(2): 166-172. DOI: 10.1016/j.scienta.2007.03.010.

IRRI 2005. IRRISTAT for Windows: a statistical package for analysis of data. International Rice Research Institute, Los Baños, Philippines.

Jain N., Dhawan K., Malhotra S.P., Siddiqui S., Singh R. 2001. Compositional and enzymatic changes in guava (Psidium guajava $\mathrm{L}$.) fruits during ripening. Acta Physiologiae Plantarum 23(3): 357-362. DOI: 10.1007/s11738-001-0044-7.

Kabele Ngiefu C.K., Paquot C., Vieux A. 1977. Les plantes à huile du Zaïre. 3. Familles botaniques fournissant des huiles d'insaturation relativement élevée. Oléagineux 32(12): 535-537. [in French]

Kitinoja L., Kader A.A. 2002. Small-Scale Postharvest Handling Practices: A Manual for Horticultural Crops, 4th ed. Postharvest Horticulture Series 8E. Postharvest Technology Research and Information Center, University of California, Davis, USA, 260 p. 
Liu K., Li H., Yuan C., Huang Y., Chen Y., Liu J. 2015. Identification of phenological growth stages of sugar apple (Annona squamosa L.) using the extended BBCH-scale. Scientia Horticulturae 181: 76-80. DOI: 10.1016/j.scienta.2014.10.046.

Ma N.V., Hong L.V., Phong O.X. 2013. Methods in Plant Physiology. Hanoi National University Publishing House, Vietnam, 223 p. [in Vietnamese]

Ma C., Chen Y., Chen J., Li X., Chen Y. 2017. A review on Annona squamosa L.: Phytochemicals and biological activities. American Journal of Chinese Medicine 45(5): 933-964. DOI: 10.1142/s0192415x17500501.

Mondal K., Malhotra S.P., Jain V., Singh R. 2009. Oxidative stress and antioxidant systems in guava (Psidium guajava L.) fruits during ripening. Physiology and Molecular Biology of Plants 15(4): 327-334. DOI: $10.1007 / \mathrm{s} 12298-009-0037-3$.

Mui N.V. 2001. Practice in Biochemistry, 2nd ed. Technology and Science Publishing House, Hanoi, Vietnam, 205 p. [in Vietnamese]

Pal D.K., Sampath Kumar P. 1995. Changes in the physico-chemical and biochemical compositions of custard apple (Annona squamosa L.) fruits during growth, development and ripening. Journal of Horticultural Science 70(4): 569-572. DOI: 10.1080/14620316.1995.11515328.

Pandey V.P., Awasthi M., Singh S., Tiwari S., Dwivedi U.N. 2017. A comprehensive review on function and application of plant peroxidases. Biochemistry and Analytical Biochemistry 6(1); 308; 16 p. DOI: 10.4172/2161-1009.1000308.

Paull R.E., Deputy J., Chen N.J. 1983. Changes in organic acids, sugars, and headspace volatiles during fruit ripening of soursop (Annona muricata L.). Journal of the American Society for Horticultural Science 108(6): 931-934.

Pimpalpalle L.V., Khandare V.S., Gaonkar Y.A. 2018. Effect of post-harvest chemical treatments on physico-chemical quality and shelf life of custard apple (Annona squamosa L.) during storage. International Journal of Current Microbiology and Applied Sciences 6(Special Issue): 1649-1658.

Prasanna V., Prabha T.N., Tharanathan R.N. 2007. Fruit ripening phenomena - an overview. Critical Reviews in Food Science and Nutrition 47(1): 1-19. DOI: 10.1080/10408390600976841.

Resende E.C.O., Martins P.F., de Azevedo R.A., Jacomino A.P., Bron I.U. 2012. Oxidative processes during 'Golden' papaya fruit ripening. Brazilian Journal of Plant Physiology 24(2): 85-94. DOI: 10.1590/s1677-04202012000200002.

Seymour G.B., Taylor J.E., Tucker G.A. 2012. Biochemistry of Fruit Ripening. Springer, Dordrecht, 454 p. DOI: 10.1007/978-94-011-1584-1.
Singh R., Dwivedi U.N. 2008. Effect of Ethrel and 1methylcyclopropene (1-MCP) on antioxidants in mango (Mangifera indica var. Dashehari) during fruit ripening. Food Chemistry 111(4): 951-956. DOI: 10.1016/j.foodchem.2008.05.011.

Singh R.K., Ali S.A, Nath P., Sane V.A. 2011. Activation of ethylene-responsive $p$-hydroxyphenylpyruvate dioxygenase leads to increased tocopherol levels during ripening in mango. Journal of Experimental Botany 62(10): 3375-3385. DOI: 10.1093/jxb/err006.

Souleyre E.J.F., Iannetta P.P.M., Ross H.A., Hancock R.D., Shepherd L.V.T., Viola R. et al. 2004. Starch metabolism in developing strawberry (Fragaria $\times$ ananassa) fruits. Physiologia Plantarum 121(3): 369-376. DOI: 10.1111/j.0031-9317.2004.0338.x.

Souza F.T.C., Santos E.R, da Cruz Silva J., Valentim I.B., Rabelo T.C.B., de Andrade N.R.F, de Souza Silva L.K. 2018. Production of nutritious flour from residue custard apple (Annona squamosa L.) for the development of new products. Journal of Food Quality 2018(Special Issue); 5281035; 10 p. DOI: 10.1155/2018/5281035.

Trong L.V, Tuong L.Q, Thinh B.B., Khoi N.T., Trong V.T. 2019. Physiological and biochemical changes in tomato fruit (Solanum lycopersicum L.) during growth and ripening cultivated in Vietnam. Bioscience Research 16(2): 1736-1744.

Trong L.V., Khanh N.N. 2020a. Physiological and biochemical changes during growth and development of persimmon fruit (Diospyros kaki L.) grown in Vietnam. Plant Archives 20(2): 6389-6394.

Trong L.V., Khanh N.N., Huyen L.T., Lam L.T. 2020 b. Changes in physiological and biochemical parameters during growth and development of mango (Mangifera indica L.) fruit in Vietnam. Journal of Applied Horticulture 22(2): 137-142. DOI: 10.37855/jah.2020.v.22i02.25.

Wills R.B.H., McGlasson W.B., Graham D., Joyce D.C. 1998. Postharvest: An introduction to the physiology and handling of fruit, vegetables and ornamentals, 4th ed. UNSW Press, CABI, 262 p.

Wills R.B.H., McGlasson W.B., Graham D., Joyce D.C. 2007. Postharvest: An introduction to the physiology and handling of fruit, vegetables and ornamentals, 5th ed. UNSW Press, CABI, 227 p.

Yadav D.K., Singh N., Dev K., Sharma R., Sahai M., Palit G., Maurya R. 2011. Anti-ulcer constituents of Annona squamosa twigs. Fitoterapia 82(4): 666675. DOI: 10.1016/j.fitote.2011.02.005.

Yang H., Li X., Tang Y., Zhang N., Chen J., Cai B. 2009. Supercritical fluid $\mathrm{CO}_{2}$ extraction and simultaneous determination of eight annonaceous acetogenins in Annona genus plant seeds by HPLC-DAD method. Journal of Pharmaceutical and Biomedical Analysis 49(1): 140-144. DOI: 10.1016/j.jpba.2008.09.055. 